\title{
Genetic Evaluation for Fruit Yield and Related Traits in Parthenocarpic Cucumber
}

\author{
Palvi Mehta* and Parveen Sharma \\ Department of Vegetable Science and Floriculture, College of Agriculture, CSK Himachal \\ Pradesh Krishi Vishvavidyalaya, Palampur- 176062, India \\ *Corresponding author
}

\begin{tabular}{l} 
K e y w o r d s \\
Parthenocarpic \\
cucumber, \\
Variability, Yield, \\
Heritability, \\
Genetic advance \\
\hline Article Info \\
$\begin{array}{l}\text { Accepted: } \\
\text { 12 September } 2020 \\
\text { Available Online: } \\
\text { 10 October } 2020\end{array}$ \\
\hline
\end{tabular}

\section{Keywords}

Parthenocarpic cucumber,

Variability, Yield Heritability, Genetic advance

Accepted:

Available Online

10 October 2020

\section{A B S T R A C T}

The present investigation entitled, "Genetic evaluation for fruit yield and related traits in parthenocarpic cucumber" was undertaken at 'Vegetable Research Farm' of the Department of Vegetable Science and Floriculture, CSKHPKV Palampur with the objectives to estimate nature of variation and to identify the most promising genotypes of parthenocarpic cucumber. The experimental material comprising of 12 genotypes including two checks were evaluated in Randomized Block Design with three replications during spring-summer, 2018 and data were recorded on marketable yield and related traits. The analysis of variance revealed that mean sum of squares due to genotypes were significant for all the characters namely days to anthesis of first female flower, nodal position of first female flower, number of female flowers per node, days taken to first fruit harvest, fruit length $(\mathrm{cm})$, fruit girth $(\mathrm{cm})$, fruit weight $(\mathrm{g})$, number of fruits per plant, marketable yield per plant $(\mathrm{kg})$, harvest duration (days), internodal length $(\mathrm{cm})$, vine length $(\mathrm{m})$, total soluble solids ( Brix), incidence of powdery mildew disease (\%) and incidence of downy mildew disease $(\%)$ that indicated the presence of sufficient genetic variability in the germplasm. Based upon overall performance, genotypes viz., Kian, DDPCG1 and Rucha found to be the most promising for marketable yield per plant as compared to other genotypes and Kian also outperformed for number of fruits per plant, fruit weight, fruit girth and vine length. High PCV and GCV estimates were obtained for number of female flowers per node which indicated that there is substantial variability ensuring ample scope for improvement of this trait through selection. High heritability coupled with high genetic advance was observed for number of female flowers per node and marketable yield per plant which indicated the importance of additive gene action for the inheritance of these traits and further improvement could be done through phenotypic selection.

\section{Introduction}

Cucumber (Cucumis sativus $\mathrm{L}$., $2 \mathrm{n}=2 \mathrm{x}=14$ ), is one of the most economically valuable vegetable species of the family
Cucurbitaceae. It is believed to be originated in India (Harlan, 1975) because of the fact that its progenitor Cucumis sativus var. hardwickii, is found in the foot hills of the Himalayan mountains and is being used by 
native people of Northern India (Deakin et al., 1971). China is considered as secondary centre of genetic diversification of Cucumis sativus (Candolle, 1882). It is cultivated in India for more than 3000 years, from where it spread Eastward to China and Westward to Asia Minor, North Africa and Southern Europe (Seshadri and Parthasarathy, 2002).

It is a low energy and high water content vegetable and its immature fruits are being eaten as refreshing salad vegetable. It is a primary source of minerals and vitamins for human body but its nutritional and caloric value is very low (Keopraparl, 1997). The nutritive value per $100 \mathrm{~g}$ edible portion of cucumber includes $0.4 \mathrm{~g}$ protein, $96.3 \mathrm{~g}$ water, $0.4 \mathrm{~g}$ fibre, $0.1 \mathrm{~g}$ fat, $2.5 \mathrm{~g}$ carbohydrates and $13 \mathrm{kcal}$ energy (Fageria et al., 2012). It is considered useful for people suffering from kidney problems, jaundice, constipation and indigestion. According to Unani system of medicine, the cucumber seed oil is considered good for brain and body.

Cucumber is one of the most suitable vegetable grown under protected conditions in the developed countries. This is primarily due to year around high demand of cucumber. In India cucumber has been also cultivated traditionally in riverbeds for off season supply. However, being a high value and low volume crop, its exploitation on commercial scale in naturally ventilated polyhouse during off season can generate good income and high profits to the growers. Parthenocarpic cucumber cultivars are most suited for protected conditions. Parthenocarpy is the phenomenon by which fruits are developed without pollination, which makes the fruit seedless. The inheritance of parthenocarpy in cucumber is governed by an incomplete dominant gene P. In homozygous condition PP produces parthenocarpic fruits early, with the first developing fruit generally by the fifth node. Heterozygous Pp plants produce parthenocarpic fruits later than homozygous plants and fewer in number. The homozygous recessive pp produces no parthenocarpic fruits.

Considering the year round increasing demand of high quality parthenocarpic slicing cucumber in the markets of the metro cities and other big cities of the country, this is one of the most profitable crop for cultivation under naturally ventilated polyhouses in periurban areas of the country. Annually three successful crops of cucumber can be obtained in a naturally ventilated polyhouse. Now the time has come when the vegetable growers in different regions of the country can use naturally ventilated polyhouse technology for cultivation of high value vegetables to get high profits (Singh, 2012). As compared to open field cultivation, very high yield of cucumber has been reported under naturally ventilated polyhouse (Srivastava and Singh, 1997). Cultivation of parthenocarpic cucumber under the protected environment having partial/fully environment control has been undertaken during last three decades in our country and very little work has been done for developing varieties for the protected environment. As on today, majority of the farmers are growing private sectors hybrid seeds of parthenocarpic cucumber with varying success and cost of the seed is also very high and beyond the approach of the common farmers. Thus, there is a need to develop public sector cultivars suitable for protected cultivation in different seasons and regions of the country. In Himachal Pradesh, no systemic work has been carried out till date for evaluation of parthenocarpic cultivars under the protected environment. Considering the importance of this crop, there is an urgent need for development of parthenocarpic varieties suitable for year around cultivation of cucumber in modified naturally ventilated polyhouses. But, before coming out with any superior variety, genetic evaluation of 
available germplasms for various qualitative and quantitative characters has to be done under modified naturally ventilated polyhouses.

\section{Materials and Methods}

The present investigation entitled "Genetic evaluation for fruit yield and related traits in parthenocarpic cucumber" were conducted at experimental farm of the Department of Vegetable Science and Floriculture, CSK Himachal Pradesh Krishi Vishvavidyalaya, Palampur, during spring-summer months of 2018.

\section{Experimental site}

\section{Location}

The present study was carried out in modified naturally ventilated polyhouse $(25 \times 10 \mathrm{~m})$ constructed with East-West orientation at vegetable farm situated at $32^{\circ} 6^{\prime} \mathrm{N}$ latitude and $76^{\circ} 3^{\prime} \mathrm{E}$ longitude at an elevation of $1,290.80 \mathrm{~m}$ above mean sea level.

\section{Climatic conditions}

The climatic condition of the experimental farm area was characterized by severe winters and mild summers. Agro-climatically, this area comes under the mid-hill zone of Himachal Pradesh and is characterized by humid sub-temperate climate with an average rainfall of 2,500 $\mathrm{mm}$ per annum, major portion of which (about 80\%) is received during June to September. April and May are dry months and usually receive very low rainfall.

\section{Experimental materials}

The experimental material comprised of 12 genotypes including 2 checks i.e. PPC-3 and Kian. The genotypes along with their sources from where genotypes are procured are presented in Table 2.

\section{Layout plan}

Planting of healthy seedlings of the experimental material was done in Randomized Block Design (RBD) with three replications in a $25 \times 10 \mathrm{~m}$ modified naturally ventilated polyhouse. In each replication 10 plants of each genotype were planted with intra and inter row spacing of $30 \mathrm{~cm}$ and 70 $\mathrm{cm}$, respectively.

\section{Sowing of nursery, transplanting and cultural practices}

Soilless media was prepared by mixing 3 parts of cocopeat, 1 part of perlite and 1 part of vermiculite. Sowing of seeds were done on $15^{\text {th }}$ February 2018 in the plug trays after filling soilless media into cells. Well developed healthy seedlings were transplanted at 2-3 true leaf stage in the bed in polyhouse on $26^{\text {th }}$ March 2018 at spacing of $70 \times 30 \mathrm{~cm}$. Besides the application of vermicompost @ 5 tonnes per hectare, chemical fertilizers $(50 \mathrm{~kg}$ each of Nitrogen, Phosphorus and Potassium per ha) were applied in pits before transplanting. Application of liquid fertilizers (19:19:19) @ $5.0 \mathrm{~g} /$ litre of water through drip irrigation/fertigation were done thrice in a week. Fertigation was started after $3^{\text {rd }}$ week of transplanting and was stopped 15 days before final harvest. The intercultural operations i.e. hoeing, weeding and earthing up were carried out in order to ensure a healthy crop growth. Irrigation was done through drip system of irrigation and done four to five times in a week. Staking is an essential step in case of cucumber vines and seedlings at six to eight leaf stage were trained to climb on the rope twines in single stem. Observations on the characters namely days to anthesis of first female flower, nodal position of first female 
flower, number of female flowers per node, days taken to first fruit harvest, fruit length $(\mathrm{cm})$, fruit girth $(\mathrm{cm})$, fruit weight $(\mathrm{g})$, number of fruits per plant, marketable yield per plant $(\mathrm{kg})$, harvest duration (days), internodal length $(\mathrm{cm})$, vine length $(\mathrm{m})$, total soluble solids ( Brix), incidence of powdery mildew disease $(\%)$ and incidence of downy mildew disease $(\%)$ in each replication were recorded. On the basis of leaf area affected, observations were made for the incidence of powdery mildew disease and categorized according to the scale adopted by Sen and Kapoor (1974). Similarly observations for the incidence of downy mildew disease were categorized according to the scale adopted by Reuveni (1983). Total soluble solids were estimated with the help of ERMA hand refractometer. The analysis of variance for the characters were statistically analysed as per the methods given by Panse and Sukhatme (1984). The genotypic and phenotypic coefficients of variation were calculated by following methods given by Burton and De Vane (1953) as follows:

\section{Phenotypic coefficient of variation $(\mathrm{PCV}) \%=\frac{\text { T }}{\overline{\mathrm{x}}} \times 100$}

Genotypic coefficient of variation $(\mathrm{GCV}) \%=\frac{\mathrm{\sigma g}}{\overline{\mathrm{x}}} \times 100$

Where, $\sigma \mathrm{g}, \sigma \mathrm{p}$ and $\overline{\mathrm{x}}$ are genotypic standard deviation, phenotypic standard deviation and grand mean, respectively.

Heritability in broad sense $\left(\mathrm{h}_{\mathrm{bs}}^{2}\right)$ was calculated as per Burton and De Vane (1953) and Johnson et al., (1955).

Heritability $\left(h^{2}{ }_{b s}\right)=\frac{\sigma^{2} g}{\sigma^{2} g+\sigma^{2} e} \times 100$

Where, $\sigma^{2} \mathrm{~g}, \sigma^{2} \mathrm{e}$ and $\sigma^{2} \mathrm{~g}+\sigma^{2} \mathrm{e}$ are genotypic variance, environmental variance and phenotypic variances, respectively.

Expected genetic advance (GA) resulting from the selection of $5 \%$ superior individuals was calculated as per Burton and De Vane (1953) and Johnson et al., (1955).

$\mathrm{GA}=\mathrm{k} \times \sigma \mathrm{p} \times \mathrm{h}^{2}{ }_{(\mathrm{bs})}$

Where, $\mathrm{K}=2.06$ (selection differential at $5 \%$ selection intensity), $\sigma \mathrm{p}=$ phenotypic standard deviation and $\mathrm{h}^{2}{ }_{(\mathrm{bs})}=$ heritability (broad sense), respectively.

Genetic advance as percentage of mean (GA $\%)=\frac{\text { Expacted GA }}{\text { Grand mean }} \times 100$

For categorizing the magnitude of different parameters, the limits used are presented in Table 1.

\section{Statistical analysis}

By using MS-Excel and OPSTAT the statistical analysis was carried out for each character observed under the study.

\section{Results and Discussion}

\section{Analysis of variance}

The value of mean sum of squares of Analysis of Variance (ANOVA) revealed highly significant differences among the evaluated genotypes for all the characters as represented in Table 3.

The significant variation among the genotypes showed the presence of adequate variability which can be exploited through selection. Earlier workers namely Solanki and Seth (1980), Lebedeva and Turlakova (1985), Grimstad (1990), Afangideh and Uyoh (2007), Shukla et al., (2010), Golabadi et al., (2012), Lajurkar et al., (2014), Singh et al., (2017), Shah et al., (2018) and Nagamani et al., (2019) have also reported significant variation in their respective germplasm among various traits thereby supporting the experimental findings. 


\section{Mean performance of different genotypes}

The average performance of different genotypes for various traits along with ranges, grand means, standard errors, coefficients of variation and critical differences are given in Table 4, 5, 6 and 7. The mean value of genotypes for days to anthesis of first female flower varied from 20.40 to 27.73 days with grand mean of 23.41 days (Table 4). Among checks, Kian (20.40 days) was superior for this trait and have minimum days to anthesis of first female flower, whereas six genotypes viz., Kafka (21.20 days), PPC-3 (21.53 days), Rucha (21.87 days), DDPCG1 (21.93 days), DDPCG5 (23.07 days) and DDPCW1 (23.53 days) were statistically at par with the best check. Various earlier workers viz., Kushwaha et al., (2012), Lajurkar et al., (2014), Choudhary et al., (2015), Ene et al., (2016), Pushpalatha et al., (2016), Kandasamy (2017), Singh et al., (2017), Shah et al., (2018) and Sharma et al., (2019) also depicted similar significant differences for days to anthesis of first female flower. The mean value of genotypes for nodal position of first female flower ranged from 2.38 to 3.41 and grand mean for this character was 3.05 (Table 4). Among all genotypes, the check PPC-3 reported to produce first female flower at lowermost node (2.38) and no genotype found statistically at par with best check PPC3. This trait depicts the early maturity of a genotype, lower the nodal position of first female flower, earlier will be the variety in fruiting and growers fetches remunerative returns. Wide variability with respect to this particular trait was also reported by Badgujar and More (2004), Kumar et al., (2008), Yadav et al., (2009), Shukla et al., (2010), Bisht et al., (2011), Dogra (2012), Basavarajeshwari et al., (2014), Lajurkar et al., (2014), Choudhary et al., (2015), Kandasamy (2017), Pal et al., ( 2017), Singh et al., (2017), Ahirwar et al., (2018) and Shah et al., (2018). The mean value of genotypes for number of female flowers per node varied from 1.11 to
2.05 and grand mean for this character was 1.50 (Table 4). Among checks, PPC-3 (1.27) was superior for number of female flowers per node, whereas five genotypes viz., DDPCG1 (2.05), Kafka (1.87), DDPCWI (1.87), DDPCG5 (1.75) and PPC-2 (1.71) found to have significantly higher number of female flowers per node when compared to best check. Maximum number of female flowers per node was reported in genotype DDPCG1 (2.05) and was statistically at par with four other genotypes namely Kafka (1.87), DDPCWI (1.87), DDPCG5 (1.75) and PPC-2 (1.71). Earlier, wide variation for this character was also been reported by Dogra (2012) and Singh et al., (2017). The trait days taken to first fruit harvest helps to identify the early maturing strains that hold extensive importance in procuring early markets. The mean value of genotypes varied from 38.93 to 49.33 days and had grand mean of 44.20 days (Table 4). In comparison to best check Kian (41.27 days), none of the genotypes was significantly superior to check Kian, while seven genotypes namely DDPCG5 (44.60 days), Kafka (44.20 days), Infinity (43.73 days) DDPCG2 (42.73 days), DDPCW1 (42.40 days), DDPCG1 (41.73 days) and Rucha (38.93 days) were statistically at par with best check. Minimum days to harvest were taken by genotype Rucha and were statistically at par with three other genotypes including best check. Presence of wide genetic variation for days taken to first fruit harvest was earlier reported by Behera et al., (2007), Yadav et al., (2009), Gaikwad et al., (2011), Kushwaha et al., (2012), Patel et al., (2013), Basavarajeshwari et al., (2014), Lajurkar et al., (2014), Pushpalatha et al., (2016), Kandasamy (2017), Singh et al., (2017), Pal et al., (2017), Ahirwar et al., (2018), Bhagwat et al., (2018), Kumar et al., (2019) and Sharma et al., (2019).

Fruit length and girth have direct influence on the marketable yield as well as on consumer preference. Fruit having cylindrical shape 
with tenderness are highly preferred by consumers and fetch lucrative returns to the growers. All the genotypes studied indicated significant variations for fruit length that ranged from 13.01 to $17.53 \mathrm{~cm}$ with grand mean of $15.23 \mathrm{~cm}$ (Table 5). Among checks, PPC-3 $(17.53 \mathrm{~cm})$ was superior for this trait as maximum fruit length was recorded in PPC-3, whereas four genotypes viz., DDPCG2 $(15.69 \mathrm{~cm})$, Rucha $(16.50 \mathrm{~cm})$, DDPCW1 $(16.52 \mathrm{~cm})$ and DDPCG1 (16.61 $\mathrm{cm})$ were statistically at par with best check. Earlier workers viz., Gaikwad et al., (2011), Dogra (2012), Golabadi et al., (2012), Patel et al., (2013), Lajurkar et al., (2014), Pushpalatha et al., (2016), Kandasamy (2017), Bhagwat et al., (2018), Shah et al., (2018), Nagamani et al., (2019) and Sharma et al., (2019) reported wide variations with respect to fruit length. The mean value of genotypes for fruit girth ranged from 9.61 to $12.75 \mathrm{~cm}$ with grand mean of $11.09 \mathrm{~cm}$ (Table 5). Among checks, Kian $(12.75 \mathrm{~cm})$ was superior for this trait as maximum fruit girth was reported in check Kian $(12.75 \mathrm{~cm})$, while five genotypes viz., DDPCG1 (12.02 $\mathrm{cm})$, DDPCG2 $(11.97 \mathrm{~cm})$, Rucha $(11.88 \mathrm{~cm})$, DDPCW1 $(11.73 \mathrm{~cm})$ and Kafka $(11.33 \mathrm{~cm})$ were statistically at par with best check. Earlier workers viz., Dogra (2012), Ene et al., (2016), Jakhar et al., (2016), Singh et al., (2017) and Sharma et al., (2019) reported significant variations for fruit girth. Fruits with higher weight are required by the farmers in order to get more marketable yield per plant. The perusal of data (Table 5) showed a range of 100.57 to $135.58 \mathrm{~g}$ for fruit weight and had grand mean of $119.62 \mathrm{~g}$. Among the checks, Kian (135.58 g) was found superior for fruit weight, whereas genotypes viz., DDPCG1 (133.37 g), Rucha $(131.87 \mathrm{~g})$ and DDPCW1 (130.06 g) was found statistically at par with best check Kian. Wide variations for this trait were also reported by Badgujar and More (2004), Gaikwad et al., (2011), Ranjan et al., (2015),
Jakhar et al., (2016), Pushpalatha et al., (2016), Pal et al., (2017), Singh et al., (2017), Bhagwat et al., (2018), Dingal et al., (2018), Nagamani et al., (2019) and Sharma et al., (2019). Significant differences were found among all the genotypes for number of fruits per plant that varied from 18.47 to 26.12 and grand mean for this character was 22.31 (Table 5). Among the checks, Kian (26.12) was found superior for number of fruits per plant, whereas genotype DDPCG1 (25.89) was statistically at par with best check Kian. Earlier workers viz., Badgujar and More (2004), Ranjan et al., (2015), Pushpalatha et al., (2016), Kandasamy (2017), Pal et al., (2017), Singh et al., (2017), Bhagwat et al., (2018), Shah et al., (2018), Nagamani et al., (2019) and Sharma et al., (2019) also reported wide range of number of fruits per plant in their germplasm.

Marketable yield is the dependent variable which is of economic concern to both breeders and farmers. Significant differences revealed among all the genotypes for marketable yield per plant and its mean value ranged from 1.89 to $3.55 \mathrm{~kg}$ and had grand mean of $2.70 \mathrm{~kg}$ (Table 6). Among the checks, Kian $(3.55 \mathrm{~kg})$ was found superior for marketable yield per plant, whereas genotype DDPCG1 $(3.45 \mathrm{~kg})$ was statistically at par with best check Kian. Presence of wide genetic variation with respect to marketable yield per plant was also reported by Dogra (2012), Lajurkar et al., (2014), Choudhary et al., (2015), Pushpalatha et al., (2016), Kandasamy (2017), Pal et al., (2017), Singh et al., (2017), Bhagwat et al., (2018), Shah et al., (2018), Nagamani et al., (2019) and Sharma et al., (2019). Prolonged availability of marketable fruits is highly desirable attribute of the parthenocarpic cucumber and generally genotypes having prolonged harvest duration are preferred to be grown under polyhouse for getting higher yield. The perusal of data (Table 6) showed a range of 
49.74 to 59.80 days for harvest duration with grand mean of 55.15 days for this trait. Among the checks, Kian (55.87) was found superior for harvest duration and all genotypes except Kafka (50.80 days) and PPC-2 (49.74 days) were statistically at par with best check Kian. Maximum harvest duration was reported in Rucha (59.80) and found statistically at par with 7 other genotypes including both the checks i.e. PPC3 and Kian. Similar variations regarding harvest duration among different genotypes were also reported by earlier workers viz., Lajurkar et al., (2014), Pal et al., (2017), Singh et al., (2017), Shah et al., (2018) and Sharma et al., (2019). The parthenocarpic cucumber bear fruits at almost every node. Thus, plants with less internodal length are preferred for attaining higher yield. Significant differences were reported among all the genotypes for internodal length that ranged from 8.67 to $11.10 \mathrm{~cm}$ and had grand mean of $9.45 \mathrm{~cm}$ (Table 6). In present study, check Kian reported to have minimum internodal length $(8.67 \mathrm{~cm})$ and six genotypes viz., DDPCG1 $(8.78 \mathrm{~cm})$, Rucha $(8.80 \mathrm{~cm})$, PPC-3 $(8.84 \mathrm{~cm}), \quad$ DDPCG2 $(9.28 \mathrm{~cm})$, DDPCW1 $(9.28 \mathrm{~cm})$ and Kafka $(9.46 \mathrm{~cm})$ were statistically at par with best check Kian. Earlier workers viz., Golabadi et al., (2012), Choudhary et al., (2015), Pushpalatha et al., (2016), Singh et al., (2017), Ahirwar et al., (2018) and Sharma et al., (2019) also reported wide variations for internodal length among all the genotypes. Indeterminate types of cultivars having longer vine length are preferred over the semi-determinate and determinate types in high rainfall regions. Highly significant differences exist among the different cucumber genotypes with respect to vine length. The mean value of genotypes for vine length varied from 3.16 to $4.34 \mathrm{~m}$ and grand mean for this character was $3.81 \mathrm{~m}$ (Table 6). Among the checks, Kian (4.34 m) was found to have higher vine length, whereas six genotypes viz., Rucha (4.26 m),
PPC-3 (4.25 m), Kafka (4.20 m), DDPCG1 (4.18 m), DDPCG2 (4.06 m) and DDPCG4 $(3.87 \mathrm{~m})$ were statistically at par with best check Kian. Wide variations were reported for vine length by Badgujar and More (2004), Afangideh and Uyoh (2007), Shukla et al., (2010), Gaikwad et al., (2011), Dogra. (2012), Patel et al., (2013), Basavarajeshwari et al., (2014), Choudhary et al., (2015), Ranjan et al., (2015), Pushpalatha et al., (2016), Ahirwar et al., (2018), Kandasamy (2017), Pal et al., (2017), Singh et al., (2017), Shah et al., (2018) and Sharma et al., (2019).

The mean value of genotypes for total soluble solids varied from 2.25 to $3.38{ }^{\circ}$ Brix with grand mean of 2.78 Brix (Table 7). In the present study, none of the genotypes was having significantly higher TSS than the best check PPC-3 (3.27 ${ }^{\circ}$ B), whereas three genotypes viz., PPC-2 (3.38 $\left.{ }^{\circ} \mathrm{B}\right)$, DDPCWI $\left(3.37^{\circ} \mathrm{B}\right)$ and DDPCG3 $\left(3.13{ }^{\circ} \mathrm{B}\right)$ were statistically at par with best check. Maximum TSS was reported in genotype PPC-2 (3.38 $\left.{ }^{\circ} \mathrm{B}\right)$ and was statistically at par with three other genotypes including check PPC-3. Dogra (2012), Patel et al., (2013), Ranjan et al., (2015), Pal et al., (2017), Singh et al., (2017), Shah et al., (2018) and Sharma et al., (2019) have also reported significant differences for total soluble solids among all the genotypes. Significant differences were observed among all the genotypes for incidence of powdery mildew. It ranged from 13.91 to $31.13 \%$ and had grand mean of 21.89 $\%$ (Table 7). Among the checks, Kian $(14.11 \%)$ was found to have less incidence of powdery mildew, whereas none of the genotypes had significantly less incidence of powdery mildew than best check Kian. However, two genotypes viz., DDPCG1 (13.91\%) and Rucha (14.93\%) were significantly at par with best check. Minimum incidence of powdery mildew was recorded in DDPCG1 (13.91\%) and found statistically at par with genotype Kian (14.11\%) and Rucha 
(14.93\%). Hochmuth et al., (2004), Dogra (2012) and Pal et al., (2017) have also reported significant variability in incidence of powdery mildew disease. All the genotypes showed significantly different response towards incidence of downy mildew disease. It ranged from 13.79 to $23.98 \%$ and had grand mean of $20.59 \%$ (Table 7). Among the checks, Kian (19.05\%) was found to have less incidence of powdery mildew, whereas genotype Rucha (13.79\%) reported to have significantly less incidence of downy mildew than best check Kian. However, four genotypes viz., DDPCW1 (16.41\%), DDPCG1 (17.65\%), DDPCG2 (18.43\%) and Infinity $(21.74 \%)$ were significantly at par with best check. Minimum incidence of downy mildew was recorded in Rucha (13.79 $\%)$ and was statistically at par with DDPCW1 (16.41\%). Gaikwad et al., (2011) and Dogra (2012) also reported significant differences for the incidence of downy mildew disease among all the genotypes.

\section{Genetic variability studies}

\section{Parameters of variability}

For formulating an efficient breeding programme, the nature and extent of genetic variability is one of the important criteria. The estimates of phenotypic coefficient of variation (PCV) and genotypic coefficient of variation $(\mathrm{GCV})$ is helpful in predicting the extent of variation present in the genetic stocks. The estimates of genetic parameters viz., PCV (\%), GCV (\%), $\mathrm{h}_{\mathrm{bs}}^{2}(\%)$ and GA as per cent of mean for different traits are given in Table 8. The phenotypic coefficient of variation ranged from 6.62 to $24.35 \%$. High phenotypic coefficient of variation existed for number of female flowers per node $(24.35 \%)$ and marketable yield per plant (21.19\%). Moderate PCV was exhibited for total soluble solids (16.82\%), vine length (13.70\%), number of fruits per plant $(11.70 \%)$, nodal position of first female flower (11.60\%), days to anthesis of first female flower $(11.31 \%)$, fruit girth $(10.90 \%)$, fruit length $(10.81 \%)$ and fruit weight $(10.65 \%)$, while rest of the traits $v i z$., internodal length $(8.41 \%)$, days taken to first fruit harvest $(8.02 \%)$ and harvest duration $(6.62 \%)$ showed low PCV. The result are in agreement to the earlier results of various researchers i.e. low PCV estimates were reported for days taken to first fruit harvest (Saikia et al.,1995; Ullah et al., 2012; Basavarajeshwari et al., 2014; Pushpalatha et al., 2016; Pal et al., 2017). In contrary to our findings low estimation of PCV was exhibited for vine length (Ranjan et al., 2015 and Pal et al., 2017). Moderate estimates of PCV were reported for fruit length (Veena et al., 2012; Kumar et al., 2013; Pal et al., 2017), nodal position of first female flower, fruit weight (Sharma 2017), number of fruits per plant (Singh et al., 2011; Sharma 2017), days to anthesis of first female flowering (Dutta 2013), nodal position of first female flower, fruit length, fruit weight, vine length (Dogra 2012). Similarly high PCV were reported for number of female flowers per node (Dogra 2012) and marketable yield per plant (Shukla et al., 2010; Ullah et al., 2012; Kumar et al., 2013; Dutta 2013; Choudhary et al., 2015; Pushpalatha et al., 2016; Pal et al., 2017; Singh et al., 2017 and Ahirwar et al., 2018).

The phenotypic coefficient of variation alone does not reveal the relative amount of variation, hence different aspects of genetic parameters are worked out. In the experimental materials, wide range of genotypic variability was observed for the characters under investigation ranging from 4.39 to $21.42 \%$. High GCV was observed in case of number of female flowers per node (21.42\%). Moderate GCV was exhibited for marketable yield per plant (19.48\%), total soluble solids (14.27\%), vine length (11.08\%) and number of fruits per plant $(10.39 \%)$, whereas rest of the characters viz., fruit 
weight $(9.64 \%)$, nodal position of first female flower $(8.71 \%)$, days to anthesis of first female flower $(7.95 \%)$, fruit girth $(7.89 \%)$, fruit length $(7.61 \%)$, internodal length (6.66 $\%)$, days taken to first fruit harvest $(6.54 \%)$ and harvest duration $(4.39 \%)$ exhibited low GCV. These results are in consonance with the earlier findings of various researchers i.e. low GCV was reported for days taken to first fruit harvest (Saikia et al., 1995; Kumar et al., 2013; Basavarajeshwari et al., 2014; Pushpalatha et al., 2016; Pal et al., 2017), days to anthesis of first female flower (Ahirwar et al., 2018; Singh et al., 2018), fruit weight and fruit length (Sharma 2017). In contrary to our findings, low estimates of GCV was exhibited for vine length (Ranjan et al., 2015; Pal et al., 2017). Moderate GCV was reported for total soluble solids (Kumar et al., 2013), number of fruits per plant and vine length (Ahirwar et al., 2018). Dogra (2012) reported similar findings for number of female flowers per node and number of fruits per plant. High genotypic coefficient of variation was obtained for number of female flowers per node (Singh et al., 2017).

\section{Heritability and genetic advance}

\section{Heritability}

The estimates of heritability for different characters (Table 7) ranged from 43.93 to $84.47 \%$ and high to moderate heritability estimates were obtained for most of the characters. High heritability estimates existed for marketable yield per plant (84.47\%), fruit weight $(81.88 \%)$, number of fruits per plant (78.89\%), number of female flowers per node $(77.42 \%)$ and total soluble solids (71.91\%). Moderate estimates of heritability existed for days taken to first fruit harvest $(66.56 \%)$, vine length (65.36\%), internodal length (62.73\%), nodal position of first female flower (56.36\%) and fruit girth $(52.37 \%)$, while rest of the traits viz., fruit length $(49.54 \%)$, days to anthesis of first female flower (49.41\%) and harvest duration (43.93\%) had low estimates of heritability. A high estimates of heritability was recorded for marketable yield per plant (Gaikwad et al., 2011; Dogra 2012; Dutta 2013; Shah et al., 2018), fruit weight (Dogra 2012; Dutta 2013; Choudhary et al., 2015; Pushpalatha et al., 2016; Shah et al., 2018), number of fruits per plant (Shukla et al., 2010; Gaikwad et al., 2011, Veena et al., 2012; Dutta 2013; Ranjan et al., 2015; Pal et al., 2017; Pushpalatha et al., 2016; Shah et al., 2018) and total soluble solids (Dogra 2012; Shah et al., 2018). Moderate value of heritability was also recorded for vine length, nodal position of first female flower (Gaikwad et al., 2011; Ahirwar et al., 2018) and days taken to first fruit harvest (Ahirwar et al., 2018; Shah et al., 2018). In contrary, characters days to anthesis of first female flower and fruit length showed high heritability (Ahirwar et al., 2018). High heritability in broad sense indicated that large portion of phenotypic variance was attributed to the genotypic variance. The traits with high heritability estimates were less influenced by environment and selection on the basis of phenotypic performance would be reliable.

\section{Genetic advance}

High heritability doesn't mean high genetic gain and is insufficient alone to make improvement through selection based on phenotypic characters. Johnson et al., (1955) stressed that for estimation of real effect of selection, heritability along with genetic advance is more useful. Therefore, the genetic advance provides an edge over heritability as a guiding factor to breeders in the various selection programmes. In the present study, high genetic advance (expressed as per cent of mean) was exhibited for number of female flowers per node $(38.83 \%)$ and marketable yield per plant (36.87\%). Moderate genetic advance was recorded for total soluble solids 
(24.92\%), number of fruits per plant $(19.01 \%)$, vine length $(18.45 \%)$ and fruit weight $(17.96 \%)$, while low estimates for genetic advance were observed for nodal position of first female flower (13.47\%), fruit girth $(11.76 \%)$, days to anthesis of first female flower (11.51\%), fruit length (11.03\%), days taken to first fruit harvest $(10.99 \%)$, internodal length $(10.86 \%)$ and harvest duration $(5.99 \%)$. Similar to our research, high GA observed for marketable yield per plant (Choudhary et al., 2015; Kandasamy 2017; Pal et al., 2017; Singh et al., 2017; Shah et al., 2018). In contrary, high genetic advance existed for number of fruits per plant and total soluble solids (Shah et al., 2018). Moderate genetic advance was observed for fruit weight (Dogra 2012; Ranjan et al., 2015; Singh et al., 2017; Shah et al., 2018) and vine length (Singh et al., 2017). Low Genetic Advance was reported for days taken to first fruit harvest (Behera $e t$ al., 2007; Shah et al., 2018), days to anthesis of first female flower (Ahirwar et al., 2018), harvest duration, fruit girth, internodal length (Dogra 2012). The traits days to anthesis first female flower and days taken to first fruit harvest had low genetic advance were in conformity to the findings of Rastogi and Deep (1990). High to moderate heritability coupled with high to moderate genetic advance indicated that the traits are under the control of additive gene action and improvement for these traits could be brought about by phenotypic selection. Moderate to low heritability coupled with low genetic advance suggested that the inheritance of the traits are under the control of non-additive gene action and selection based on phenotypic appearance is not effective and traits can be improved through recombinant breeding.

Table.1 Limits for categorizing the magnitude of different parameters

\begin{tabular}{|l|c|c|c|}
\hline & High (\%) & Medium (\%) & Low (\%) \\
\hline PCV and GCV & $>20 \%$ & $10-20 \%$ & $<10 \%-$ \\
\hline Heritability (\%) & $>70 \%$ & $50-70 \%$ & $<50 \%$ \\
\hline Genetic advance & $>25 \%$ & $15-25 \%$ & $<15 \%$ \\
\hline
\end{tabular}

Table.2 List of 12 genotypes along with sources

\begin{tabular}{|l|l|l|}
\hline $\mathbf{1}$ & DDPCG1 & CSKHPKV, Palampur \\
\hline $\mathbf{2}$ & DDPCG2 & CSKHPKV, Palampur \\
\hline $\mathbf{3}$ & DDPCG3 & CSKHPKV, Palampur \\
\hline $\mathbf{4}$ & DDPCG4 & CSKHPKV, Palampur \\
\hline $\mathbf{5}$ & DDPCG5 & CSKHPKV, Palampur \\
\hline $\mathbf{6}$ & DDPCW1 & CSKHPKV, Palampur \\
\hline $\mathbf{7}$ & PPC-2 & GBPUA\&T, Pantnagar \\
\hline $\mathbf{8}$ & Kafka & Syngenta India Limited \\
\hline $\mathbf{9}$ & Infinity & Nunhems India Private Limited \\
\hline $\mathbf{1 0}$ & Rucha & Sanas Hitech Agro Services \\
\hline $\mathbf{1 1}$ & PPC-3( Check) & GBPUA\&T, Pantnagar \\
\hline $\mathbf{1 2}$ & Kian (Check) & Nunhems India Private Limited \\
\hline
\end{tabular}


Table.3 Analysis of variance for different characters in parthenocarpic cucumber genotypes

\begin{tabular}{|c|c|c|c|c|}
\hline \multirow[t]{2}{*}{ S.No. } & \multirow{2}{*}{$\begin{array}{c}\text { Traits } \\
\begin{array}{c}\text { Source of variation } \\
\text { df }\end{array}\end{array}$} & \multicolumn{3}{|c|}{ Mean sum of squares } \\
\hline & & $\begin{array}{c}\text { Replication } \\
2\end{array}$ & $\begin{array}{c}\text { Treatment } \\
11\end{array}$ & $\begin{array}{c}\text { Error } \\
22\end{array}$ \\
\hline 1. & Days to anthesis of first female flower & 1.399 & $13.920 *$ & 3.542 \\
\hline 2 & Nodal position of first female flower & 0.001 & $0.266^{*}$ & 0.055 \\
\hline 3 & Number of female flowers per node & 0.078 & $0.340 *$ & 0.030 \\
\hline 4 & Days taken to first fruit harvest & 4.213 & $29.265^{*}$ & 4.199 \\
\hline 5 & Fruit length $(\mathrm{cm})$ & 1.202 & $5.396^{*}$ & 1.368 \\
\hline 6 & Fruit girth $(\mathrm{cm})$ & 0.030 & $2.993 *$ & 0.696 \\
\hline 7 & Fruit weight (gm) & 6.899 & $427.881 *$ & 29.397 \\
\hline 8 & Number of fruits per plant & 0.495 & $17.554 *$ & 1.439 \\
\hline 9 & Marketable yield per plant (kg) & 0.015 & $0.877 *$ & 0.051 \\
\hline 10 & Harvest duration (days) & 9.646 & $25.053 *$ & 7.478 \\
\hline 11 & Internodal length $(\mathrm{cm})$ & 0.166 & $1.424 *$ & 0.235 \\
\hline 12 & Vine length $(\mathrm{m})$ & 0.657 & $0.630 *$ & 0.094 \\
\hline 13 & Total soluble solids ( $\mathrm{Brix})$ & 0.032 & $0.533^{*}$ & 0.061 \\
\hline 14 & Incidence of powdery mildew disease $(\%)$ & 3.061 & $94.619 *$ & 3.596 \\
\hline 15 & Incidence of downy mildew disease (\%) & 4.901 & $34.700^{*}$ & 2.641 \\
\hline \multicolumn{3}{|c|}{ *Significance at $\mathrm{P} \leq 0.05$} & & \\
\hline
\end{tabular}

Table.4 Mean performance of parthenocarpic cucumber genotypes for days to anthesis of first female flower, nodal position of first female flower, number of female flowers per node and days taken to first fruit harvest

\begin{tabular}{|l|c|c|c|c|}
\hline Genotypes mn1 & $\begin{array}{c}\text { Days to anthesis of } \\
\text { first female flower }\end{array}$ & $\begin{array}{c}\text { Nodal position of } \\
\text { first female flower }\end{array}$ & $\begin{array}{c}\text { Number of female } \\
\text { flowers per node }\end{array}$ & $\begin{array}{c}\text { Days taken to } \\
\text { first fruit harvest }\end{array}$ \\
\hline DDPCG1 & 21.93 & 3.13 & 2.05 & 41.73 \\
\hline DDPCG2 & 25.00 & 2.82 & 1.11 & 42.73 \\
\hline DDPCG3 & 27.73 & 3.40 & 1.56 & 49.33 \\
\hline DDPCG4 & 24.40 & 3.27 & 1.17 & 48.13 \\
\hline DDPCG5 & 23.07 & 3.20 & 1.75 & 44.60 \\
\hline DDPCW1 & 23.53 & 2.80 & 1.87 & 42.40 \\
\hline PPC-2 & 25.80 & 3.41 & 1.71 & 48.27 \\
\hline Kafka & 21.20 & 3.07 & 1.87 & 44.20 \\
\hline Infinity & 24.40 & 3.00 & 1.25 & 43.73 \\
\hline Rucha & 21.87 & 3.27 & 1.27 & 45.93 \\
\hline PPC-3 ( C) & 21.53 & 2.38 & 1.27 & 41.27 \\
\hline Kian ( C) & 20.40 & 2.87 & 1.14 & 1.18 \\
\hline SE (m) \pm & 1.09 & 0.13 & 0.10 & 1.67 \\
\hline SE (d) \pm & 1.54 & 0.19 & 0.14 & 3.49 \\
\hline CD (P $\leq \mathbf{0 . 0 5 )}$ & 3.21 & 0.40 & 0.30 & 4.64 \\
\hline CV (\%) & 8.04 & 7.66 & 11.59 & 44.20 \\
\hline Grand mean & 23.41 & 3.05 & 1.50 & $38.93-49.33$ \\
\hline Range & $20.40-27.73$ & $2.38-3.41$ & $1.11-2.05$ & \\
\hline
\end{tabular}


Table.5 Mean performance of parthenocarpic cucumber genotypes for fruit length $(\mathrm{cm})$, fruit girth $(\mathrm{cm})$, fruit weight $(\mathrm{g})$ and number of fruits per plant

\begin{tabular}{|l|c|c|c|c|}
\hline Genotypes & Fruit length (cm) & Fruit girth (cm) & Fruit weight (g) & $\begin{array}{c}\text { Number of fruits } \\
\text { per plant }\end{array}$ \\
\hline DDPCG1 & 16.61 & 12.02 & 133.37 & 25.89 \\
\hline DDPCG2 & 15.69 & 11.97 & 117.46 & 23.94 \\
\hline DDPCG3 & 13.01 & 10.99 & 100.57 & 19.28 \\
\hline DDPCG4 & 14.52 & 10.33 & 108.61 & 19.88 \\
\hline DDPCG5 & 14.18 & 9.61 & 112.31 & 21.01 \\
\hline DDPCW1 & 16.52 & 11.73 & 130.06 & 23.37 \\
\hline PPC-2 & 13.90 & 9.85 & 102.14 & 18.47 \\
\hline Kafka & 14.66 & 11.33 & 123.60 & 22.25 \\
\hline Infinity & 14.55 & 10.47 & 118.82 & 21.79 \\
\hline Rucha & 16.50 & 11.88 & 131.87 & 23.50 \\
\hline PPC-3 ( C) & 17.53 & 10.21 & 121.03 & 22.25 \\
\hline Kian ( C) & 15.12 & 12.75 & 135.58 & 26.12 \\
\hline SE (m) \pm & 0.68 & 0.48 & 3.13 & 0.69 \\
\hline SE (d) \pm & 0.95 & 0.68 & 4.43 & 0.98 \\
\hline CD (P $\leq \mathbf{0 . 0 5 )}$ & 1.99 & 1.42 & 9.23 & 2.04 \\
\hline CV (\%) & 7.68 & 7.52 & 4.53 & 5.38 \\
\hline Grand mean & 15.23 & 11.09 & 119.62 & 22.31 \\
\hline Range & $13.01-17.53$ & $9.61-12.75$ & $100.57-135.58$ & $18.47-26.12$ \\
\hline
\end{tabular}

Table.6 Mean performance of parthenocarpic cucumber genotypes for marketable yield per plant $(\mathrm{kg})$, harvest duration (days), internodal length $(\mathrm{cm})$ and vine length $(\mathrm{m})$

\begin{tabular}{|l|c|c|c|c|}
\hline Genotypes & $\begin{array}{c}\text { Marketable yield } \\
\text { per plant } \mathbf{( k g )}\end{array}$ & $\begin{array}{c}\text { Harvest } \\
\text { duration (days) }\end{array}$ & $\begin{array}{c}\text { Internodal } \\
\text { length (cm) }\end{array}$ & Vine length (m) \\
\hline DDPCG1 & 3.45 & 57.73 & 8.78 & 4.18 \\
\hline DDPCG2 & 2.81 & 55.27 & 9.28 & 4.06 \\
\hline DDPCG3 & 1.94 & 52.60 & 9.78 & 3.26 \\
\hline DDPCG4 & 2.17 & 57.27 & 9.66 & 3.87 \\
\hline DDPCG5 & 2.36 & 56.53 & 9.70 & 3.16 \\
\hline DDPCW1 & 3.04 & 56.47 & 9.28 & 3.46 \\
\hline PPC-2 & 1.89 & 49.74 & 11.10 & 3.32 \\
\hline Kafka & 2.75 & 50.80 & 9.46 & 4.20 \\
\hline Infinity & 2.59 & 54.80 & 10.05 & 3.39 \\
\hline Rucha & 3.10 & 59.80 & 8.80 & 4.26 \\
\hline PPC-3 ( C) & 2.69 & 55.27 & 8.84 & 4.25 \\
\hline Kian ( C) & 3.55 & 55.87 & 8.67 & 4.34 \\
\hline SE (m) \pm & 0.13 & 1.58 & 0.28 & 0.18 \\
\hline SE (d) \pm & 0.18 & 2.23 & 0.40 & 0.25 \\
\hline CD (P $\leq \mathbf{0 . 0 5 )}$ & 0.38 & 4.66 & 0.83 & 0.52 \\
\hline CV (\%) & 8.35 & 4.96 & 5.13 & 8.06 \\
\hline Grand mean & 2.70 & 55.18 & 9.45 & 3.81 \\
\hline Range & $1.89-3.55$ & $49.74-59.80$ & $8.67-11.10$ & $3.16-4.34$ \\
\hline
\end{tabular}


Table.7 Mean performance of parthenocarpic cucumber genotypes for total soluble solids ( $\mathrm{B}$ ), incidence of powdery mildew disease $(\%)$ and incidence of downy mildew disease $(\%)$

\begin{tabular}{|c|c|c|c|}
\hline Genotypes & $\begin{array}{l}\text { Total soluble } \\
\text { solids ( }{ }^{\circ} \text { Brix) }\end{array}$ & $\begin{array}{l}\text { Incidence of powdery } \\
\text { mildew disease }(\%)\end{array}$ & $\begin{array}{l}\text { Incidence of downy } \\
\text { mildew disease (\%) }\end{array}$ \\
\hline DDPCG1 & 2.27 & 13.91 & 17.65 \\
\hline DDPCG2 & 2.80 & 18.20 & 18.43 \\
\hline DDPCG3 & 3.13 & 31.13 & 23.21 \\
\hline DDPCG4 & 2.78 & 25.92 & 23.98 \\
\hline DDPCG5 & 2.62 & 25.03 & 23.20 \\
\hline DDPCW1 & 3.37 & 21.18 & 16.41 \\
\hline PPC-2 & 3.38 & 28.12 & 23.88 \\
\hline Kafka & 2.25 & 22.24 & 22.85 \\
\hline Infinity & 2.49 & 23.33 & 21.74 \\
\hline Rucha & 2.30 & 14.93 & 13.79 \\
\hline PPC-3 ( C) & 3.27 & 24.61 & 22.93 \\
\hline Kian ( C) & 2.70 & 14.11 & 19.05 \\
\hline $\mathrm{SE}(\mathrm{m}) \pm$ & 0.14 & 1.09 & 0.94 \\
\hline $\mathrm{SE}(\mathrm{d}) \pm$ & 0.20 & 1.55 & 1.33 \\
\hline$C D(P \leq 0.05)$ & 0.42 & 3.23 & 2.77 \\
\hline CV $(\%)$ & 8.91 & 8.66 & 7.89 \\
\hline Grand mean & 2.78 & 21.89 & 20.59 \\
\hline Range & $2.25-3.38$ & $13.91-31.13$ & $13.79-23.98$ \\
\hline
\end{tabular}

Table.8 Estimates of PCV, GCV, heritability and genetic advance for marketable yield and other traits in parthenocarpic cucumber

\begin{tabular}{|c|c|c|c|c|}
\hline Traits & $\operatorname{PCV}(\%)$ & $\operatorname{GCV}(\%)$ & $\mathbf{h}_{\mathrm{bs}}^{2}(\%)$ & GA \\
\hline Days to anthesis of first female flower & $11.31(\mathrm{M})$ & 7.95(L) & 49.41(L) & $11.51(\mathrm{~L})$ \\
\hline Nodal position of first female flower & $11.60(\mathrm{M})$ & $8.71(\mathrm{~L})$ & $56.36(\mathrm{M})$ & $13.47(\mathrm{~L})$ \\
\hline Number of female flowers per node & $24.35(\mathrm{H})$ & $21.42(\mathrm{H})$ & $77.42(\mathrm{H})$ & $38.83(\mathrm{H})$ \\
\hline Days taken to first fruit harvest & $8.02(\mathrm{~L})$ & $6.54(\mathrm{~L})$ & $66.56(\mathrm{M})$ & $10.99(\mathrm{~L})$ \\
\hline Fruit length $(\mathrm{cm})$ & $10.81(\mathrm{M})$ & 7.61(L) & 49.54(L) & $11.03(\mathrm{~L})$ \\
\hline Fruit girth (cm) & $10.90(\mathrm{M})$ & $7.89(\mathrm{~L})$ & $52.37(\mathrm{M})$ & $11.76(\mathrm{~L})$ \\
\hline Fruit weight (g) & $10.65(\mathrm{M})$ & $9.64(\mathrm{~L})$ & $81.88(\mathrm{H})$ & $17.96(\mathrm{M})$ \\
\hline Number of fruits per plant & $11.70(\mathrm{M})$ & $10.39(\mathrm{M})$ & $78.89(\mathrm{H})$ & $19.01(\mathrm{M})$ \\
\hline Marketable yield per plant (kg) & $21.19(\mathrm{H})$ & $19.48(\mathrm{M})$ & $84.47(\mathrm{H})$ & $36.87(\mathrm{H})$ \\
\hline Harvest duration (days) & $6.62(\mathrm{~L})$ & 4.39(L) & 43.93(L) & 5.99(L) \\
\hline Internodal length (cm) & $8.41(\mathrm{~L})$ & $6.66(\mathrm{~L})$ & $62.73(\mathrm{M})$ & $10.86(\mathrm{~L})$ \\
\hline Vine length (m) & $13.70(\mathrm{M})$ & $11.08(\mathrm{M})$ & $65.36(\mathrm{M})$ & $18.45(\mathrm{M})$ \\
\hline Total soluble solids ( ${ }^{\circ}$ Brix) & $16.82(\mathrm{M})$ & $14.27(\mathrm{M})$ & 71.91(H) & 24.92(M) \\
\hline
\end{tabular}

PCV: Phenotypic Coefficient of Variation $\{>20 \%$ - High (H), $10-20 \%$ - Moderate(M), <10\% - Low(L) GCV: Genotypic Coefficient of Variation $\{>20 \%$ - High (H), $10-20 \%$ - Moderate (M), <10\% - Low(L) $\}$ $\mathrm{h}_{\mathrm{bs}}^{2}(\%)$ : Heritability in broad sense $\{>70 \%-\operatorname{High}(\mathrm{H}), 50-70 \%$ - Moderate $(\mathrm{M}),<50 \%$ - Low $(\mathrm{L})\}$ Genetic Advance (\%) of mean $\{>25 \%$ - High $(\mathrm{H}), 15-25 \%$ - Moderate (M), <15\% - Low(L) $\}$ 
It is concluded in this study, parthenocarpic cucumber genotypes namely Kian, DDPCG1 and Rucha were found to be superior for marketable yield and related traits. The top performing genotype Kian also outperformed for number of fruits per plant, fruit weight, fruit girth, vine length, days to anthesis of first female flower, nodal position of first female flower and internodal length. Similarly, DDPCG1 outperformed for number of female flowers per node and resistance against incidence of powdery mildew disease, Rucha outperformed for days taken to first fruit harvest, harvest duration and resistance against incidence of downy mildew disease, PPC-3 and PPC-2 outperformed for fruit length and total soluble solids, respectively. PCV and GCV estimates were high for number of female flowers per node indicating the presence of substantial variability ensuring ample scope for improvement through selection. High heritability along with high genetic advance were recorded for traits namely marketable yield per plant and number of female flowers per node indicated the importance of additive gene action for the inheritance of these traits and further improvement could be done through phenotypic selection.

\section{References}

Afangideh U and Uyoh EA. 2007. Genetic variability and correlation studies in some varieties of cucumber (Cucumis sativus L.). Jordan Journal of Agricultural Sciences 3: 376-384

Ahirwar CS and Singh DK. 2018. Assessment of genetic variability in cucumber (Cucumis sativus L.) International Journal of Current Microbiology and Applied Sciences 7: 813-822

Badgujar CD and More TA. 2004. Off season performance of selected tropical gynoecious cucumber hybrids grown under different regimes. South Indian
Horticulture 52: 97-103

Basavarajeshwari, Mulge R, Nagaraja KS, Srikant LG, Mahamad THN, Raveendra YC and Gowda HV. 2014. Genetic variability, heritability and genetic advance for yield and yield parameters and fruit and seed quality parameters in cucumber (Cucumis sativus L.). Trends in Biosciences 7:1965-1967

Behera TK, Kumar R, Panda B and Munshi AD. 2007. Genetic variability in Cucumis sativus var. hardwickii $\mathrm{R}$. (Alef) germplasm. Cucurbit Genetics Cooperative Report 30: 5-10

Bhagwat A, Srinivasa V, Bhammanakati S and Shubha AS. 2018. Evaluation of cucumber (Cucumis sativus L.) genotypes under hill zone of Karnataka, India. International Journal of Current Microbiology and Applied Sciences 7: 837-842

Bisht B, Singh MP, Srivastava BK and Singh PK. 2011. Performance of cucumber varieties in a naturally ventilated polyhouse. Indian Journal of Horiculture 68: 575-577

Burton GW and De Vane EH. 1953. Estimating heritability in tall fescue (Festuca arundinacea) from replicated clonal material. Agronomy Journal 54: 478-481

Candolle AD. 1882. Origin of cultivated plant. New York. p 457

Choudhary H, Singh DK and Damke SR. 2015. Genetic variability in Cucumis sativus var. hardwickii: key to cucumber improvement. International Journal of Basic and Applied Agricultural Research 13: 340-343

Deakin JR, GW Bohn and TW Whitaker. 1971. Interspecific hybridization in Cucumis. Economic Botany 25:195211

Dogra LK. 2012. Genetic evaluation of some hybrids of cucumber under modified 
naturally ventilated greenhouse in mid hills of Western Himalayas. M.Sc. Thesis, $\mathrm{p}$ 92. Department of Vegetable Science and Floriculture, CSK Himachal Pradesh Krishi Vishvavidyalaya, Palampur, India

Dutta RK. 2013. Study on genetic variability, heritability, genetic advance, correlation and path coefficient analysis in diverse genotypes of cucumber (Cucumis sativus L.) M.Sc. Thesis, $\mathrm{p}$ 49. Institute of Agricultural Sciences, Banaras Hindu University, Varanasi, India

Ene CO, Ogbonna PE, Agbo CU and Chukwudi UP. 2016. Studies of phenotypic and genotypic variation in sixteen cucumber genotypes. Chilean Journal of Agricultural Research 76: 307-313

Fageria MS, Choudhary BR and Dhaka RS. 2012. Cucurbits- A text book on production technology of vegetables. Kalyani publisher. New Delhi. p 184

Gaikwad AG, Sonawane HG, Dhumal SS and Musmade AM. 2011. Variability studies in cucumber (Cucumis sativus L.). Asian journal of Horticulture 6: 148-150

Golabadi M, Golkar P and Eghtedary AR. 2012. Assessment of genetic variation in cucumber (Cucumis sativus L.) genotypes. European Journal of Experimental Biology 2: 1382-1388

Grimstad SO. 1990. Evaluation trials of greenhouse cucumbers. Gartneryrket 80: $16-18$

Harlan JR. 1975. Crops and Man. American Society of Agronomy, Crop Science Society of America, Madison, WI.

Hochmuth RC, Davis LLL, Laughlin WL, Simonne EH, Sargent SA and Berry A. 2004. Evaluation of twelve greenhouse beit-alpha cucumber varieties and two growing systems. Acta Horticulturae 659: 461-466
Jakhar RK, Singh AK and Kumawat N. 2016. Yield attributes and yield of cucumber (Cucumis sativus L.) cultivars as influenced by growing conditions in arid zone of Rajasthan. Environment and Ecology 34: 2258-2261

Johnson HW, Robinson HF and Comstock RE. 1955. Estimates of genetic and environmental variability in soyabean. Agronomy Journal 47: 314-318

Kandasamy R. 2017. Variability studies in cucumber (Cucumis sativus L.). The Asian Journal of Horticulture 12: 8487

Keopraparl K. 1997. Comparison of local cucumber varieties homudonthani with commercial varieties. Asian Regional center- AVRDC, Bangkok, Thailand. p 5.

Kumar A, Kumar S and Pal AK. 2008. Genetic variability and characters association for fruit yield and yield traits in cucumber. Indian Journal of Horticulture 65: 423-428

Kumar P, Khapte PS, Saxena A and Kumar. 2019. Evaluation of gynoecious cucumber (Cucumis sativus) hybrids for early-summer greenhouse production in Western Indian arid plains. Indian Journal of Agricultural Sciences 89: 545-550

Kumar S, Kumar D, Kumar R, Thakur KS and Dogra BS. 2013. Estimation of genetic variability and divergence for fruit yield and quality traits in cucumber (Cucumis sativus L.) in North-Western himalayas. Universal Journal of Plant Science 1: 27-36

Kushwaha ML, Yadav LB, Singh VP, Maurya RP and Mishra SK. 2012. Evaluation trial on cucumber (Cucumis sativus L.) hybrid under polyhouse. National seminar on protected cultivation of vegetables and flowers- A value chain approach. G.B. Pant University of Agriculture and Technology, 
Pantnagar, Uttrakhand, India, p 6

Lajurkar VG, Mali PC, Haldavanekar PC, Parulekar YR, Magarand VG and Phutankar NR. 2014. Evaluation of $F_{1}$ hybrids of cucumber (Cucumis sativus L.) under naturally ventilated polyhouse. Journal of Indian Society of Coastal Agriculture Research 32: $55-58$

Lebedeva AT and Turlakova VG. 1985. Fruit formation and yield of parthenocarpic cucumber hybrids. Selektsiya ovoshchnykh kul'tur, Moscow, USSR

Nagamani GV, Kumar JSA, Reddy TBM, Rajesh AM, Amarananjundeswara $\mathrm{H}$, Reddy RLR and Doddabasappa B. 2019. Performance of different parthenocarpic cucumber (Cucumis sativus L.) hybrids for yield and yield attributing traits under shade net house. International Journal of Current Microbiology and Applied Sciences 8: 978-982

Pal S, Sharma HR, Rai AK and Bhardwaj RK. 2017. Genetic variability, heritability and genetic gain for yield and quality traits in cucumber (Cucumis sativus L.). An International Quarterly Journal of Life Sciences 11: 19851990

Panse VG and Sukhatme PV. 1984. Statistical Methods for Agricultural Workers. Indian Council of Agricultural Research, Publication, New Delhi. p 359

Patel JK, Bahadur V, Singh D, Prasad VM and Rangare SB. 2013. Performance of cucumber (Cucumis sativus L.) hybrids in agro-climatic conditions of Allahabad. HortFlora Research Spectrum 2: 50-55

Pushpalatha N, Anjanappa M, Devappa V and Pitchaimuthu M. 2016. Genetic variability and heritability for growth and yield in cucumber (Cucumis sativus L.). Journal of Horticulture
Sciences 11: 33-36

Ranjan P, Gangopadhyay KK, Bag MK, Roy A, Srivastava R, Bhardwaj $R$ And Dutta M. 2015. Evaluation of cucumber (Cucumis sativus L.) germplasm for agronomic traits and disease resistance and estimation of genetic variability. Indian Journal of Agricultural Sciences 85: 234239

Rastogi KB and Deep A. 1990. A note on inter-relationship between yield and important plant characters of cucumber (Cucumis sativus L.). Vegetable Science 17: 102-104

Reuveni R. 1983. Resistance reaction of Cucumis melo to inoculation with Pseudoperonospora cubensis. Annals of Applied Biology 102: 533-537

Saikia J, Shadeque A and Bora GC. 1995. Genetic studies in cucumber: correlation and path coefficient analysis. Haryana Journal of Horticultural Sciences 24: 126-130

Sen B and Kapoor IJ. 1974. Field trials of systemic and non-systemic fungicides against powdery mildew of cucurbits. Pesticides 8: 43-46

Shah KN, Rana DK and Singh V. 2018. Evaluation of genetic variability, heritability and genetic advance in cucumber (Cucumis sativus L.) for various quantitative, qualitative and seed characters. International Journal of Current Microbiology and Applied Sciences 7: 3296-3303

Sharma P, Dhillon NS, Kumar P and Mehta P. 2019. Evaluation of parthenocarpic cucumber genotypes for fruit yield and its contributing traits under protected environment of N-W Himalayas. International Journal of Chemistry Studies 3: 04-06

Sharma S. 2017. Genetic divergence studies in cucumber (Cucumis sativus L.). M.Sc. Thesis, p 60. Department of Vegetable Science, Dr. Y S Parmar 
University of Horticulture and Forestry, Nauni, Solan, India

Shukla IN, Sunder S, Singh DK, Singh N, Pandey R and Awasthi PN. 2010. Genetic variability and selection parameters for fruit yield in cucumber (Cucumis sativus L.). Current Advances in Agricultural Sciences 2: $107-108$

Singh B. 2012. Protected cultivation technologies for diversification and livelihood security. National seminar on protected cultivation of vegetables and flowers- A value chain approach. G.B. Pant University of Agriculture and Technology, Pantnagar, Uttrakhand, India, p 27-32

Singh SK, Singh A and Gangwar LK. 2011. Variability and heritability studies in cucumber. Progressive Agriculture 11:166-167

Singh SS, Yadav GC and Kathayat K. 2018. Study of genetic variability in cucumber. Journal of Hill Agriculture 9: $39-43$

Singh Y, Safiullah, Verma A, Sharma S and Sekhon BS. 2017. Genetic evaluation of cucumber (Cucumis sativus L.) genotypes for yield and its contributing traits under mid-hill conditions of Himachal Pradesh,
India. Environment \& Ecology 35: 3621-3626

Solanki SS and Seth JN. 1980. Correlation studies in cucumber (Cucumis sativus L.). Vegetable Science 7: 94-101

Srivastava BK and Singh MP 1997. Boosting off-season production of vegetable in low cost polyhouse. In: Proceedings of III $^{\text {rd }}$ Agricultural Science Congress, Punjab Agricultural University, Ludhiana, Punjab, India.

Ullah MZ, Hasan MJ, Chowdhury AZMKA, Saki AI and Rahman AHMA. 2012. Genetic variability and correlation in exotic cucumber (Cucumis sativus L.) varieties. Bangladesh J.ournal of Plant Breeding and Genetics. 25: $17-$ 23

Veena R, Sidhu AS, Pitchaimuthu $M$ and Souravi K. 2012. Genetic evaluation of cucumber (Cucumis sativus L.) genotypes for some yield and related traits. Electronic Journal of Plant Breeding 3: 945-948

Yadav YC, Kumar S, Brijpal B and Dixit SK. 2009. Genetic variability, heritability and genetic advance for some traits in cucumber. Indian Journal of Horticulture 66: 488-491.

\section{How to cite this article:}

Palvi Mehta and Parveen Sharma. 2020. Genetic Evaluation for Fruit Yield and Related Traits in Parthenocarpic. Int.J.Curr.Microbiol.App.Sci. 9(10): 1388-1404. doi: https://doi.org/10.20546/ijcmas.2020.910.166 